\title{
Peritoneal Spaces. Measurements of peritoneal surfaces
}

\author{
Espacios Peritoneales. Mediciones de las Superficies Peritoneales
}

\author{
Alfonso M. Albanese ${ }^{1}$; Alicia B. Merlo²; Marta G. Gomez ${ }^{3}$; Jorge H. Miño ${ }^{4}$; Adriana V. Ingratta ${ }^{5}$ \& Eduardo F. Albanese
}

ALBANESE, A. M.; MERLO, A. B.; GOMEZ, M. G.; MIÑO, J. H.; INGRATTA, A. V. \& ALBANESE, E. F. Peritoneal spaces.

Measurements of peritoneal surfaces. Int. J. Morphol. 37(2):730-734, 2019.

SUMMARY: In this work the quantitative data of the surfaces that limit the sub-spaces that constitute the peritoneal space are shown. The methodology of measurement of the two sheets (parietal and visceral) of the peritoneal serosa applied in our previous paper (Albanese et al., 2009), in non-eviscerated corpses, allowed us to know for the first time, the surface or total extension of the peritoneum "in situ". This methodology was useful to determine the surface or area of the two sheets of the peritoneum, which limit the peritoneal space. Our objective in this study was to determine the total peritoneal areas (visceral + parietal) in human corpses that are not eviscerated, which limit the different sub-spaces that make up the peritoneal space. Ten female cadavers fixed in $5 \%$ formaldehyde solution were used. Small cellophane films were placed directly on the peritoneal sheets. The digital images were obtained by scanning these models. The surface was determined by the "Scion image for Windows" program. The results were expressed as mean $+/-$ SE. The analysis of variance (ANOVA) was used for the statistical study. The results obtained showed that the peritoneal sub-space of greater surface area was retro-omental (mean +/- SE $7767.81+/-646.70 \mathrm{~cm}^{2} \mathrm{p}<0.01$ ANOVA), due to the large extension of its visceral surface $($ mean $+/$ - SE $\left.7401.82+/-640.99 \mathrm{~cm}^{2}\right)$. More than $50 \%$ of the surface of the entire peritoneum corresponds to said sub-space. The smallest peritoneal sub-space ( $3 \%$ of the total peritoneal surface) was the pelvic sub-space (mean $+/-$ SE $431.30+/-41.62 \mathrm{~cm}^{2}$ ). We believe that this information may be useful in case of peritoneal pathological processes or those affected by prolonged peritoneal dialysis, and that knowledge of the surface and extension of the peritoneal space involved may contribute to the estimation of the peritoneal surface involved and help to plan the treatment.

KEY WORDS: Peritoneal space; Peritoneum; Morphometry; Human anatomy.

\section{INTRODUCTION}

The peritoneum is the largest serous membrane in the human body. The peritoneal space is limit by visceral and parietal peritoneum. The parietal peritoneum is applied against the abdominal walls and the visceral peritoneum is reflected over the contained viscera and lubricated by a small quantity of serous fluid (Williams, 1995).

The peritoneal space is subdivided into interconnected sub-spaces. The qualitative and quantitative characteristics of these sub-spaces is a fact of clinical interest in abdominal pathology, peritoneal pathology, peritoneal dialysis and surgical techniques. In the bibliography consulted, we have not found papers that describe quantitative data of these surfaces that limit peritoneal subspaces.
In order to know the extension of these surfaces we have used an own methodology of measurement of the peritoneal serous to obtain reliable values "in situ". The methodology applied by Esperanca \& Collins (1966) and Rubin et al. (1988) for measurements of the total peritoneal space did not provide reliable information of the peritoneal "in situ" dimension due to deformations by the evisceration process. The measurement methodology of peritoneal serous applied in our previous paper (Albanese et al.) in noneviscerated cadavers, allowed us to know for first time, the total extension of the peritoneum in situ.

Such methodology we believe is useful for determining surface values of both peritoneal sheets that limit the sub-spaces that form the peritoneal space. The objective

\footnotetext{
${ }^{1}$ Profesor Titular Emérito. Cátedra de Anatomía. Facultad de Medicina. Universidad del Salvador, Buenos Aires, Argentina.

${ }^{2}$ Investigadora Principal. Instituto de Investigaciones. Facultad de Medicina. Universidad del Salvador, Buenos Aires, Argentina.

${ }^{3}$ Profesora Adjunta. Cátedra de Anatomía. Facultad de Medicina. Universidad del Salvador, Buenos Aires, Argentina.

${ }^{4}$ Investigador Principal. Instituto de Investigaciones. Facultad de Medicina. Universidad del Salvador, Buenos Aires, Argentina.

${ }^{5}$ Profesora Titular. Cátedra de Anatomía. Facultad de Medicina. Universidad del Salvador, Buenos Aires, Argentina.
} 
in this article is to obtain in human cadavers without eviscerating the total peritoneal areas (visceral + parietal sheets) that limit the sub-spaces of the peritoneal space.

\section{MATERIAL AND METHOD}

In this paper were used ten female human cadavers and their characteristics are in Table I. They were fixed in formaldehyde $(5 \%)$ during the first 72 hours postmortem and stored in formaldehyde (5\%) for at least 150 days, before being process in order to ensure a stable volume.

Table I. Human subject characteristics $(n=10)$.

\begin{tabular}{lr}
\hline MEASURED PARAMETER & \multicolumn{1}{c}{ MEAN +/- SE } \\
\hline AGE (years) & $73.30+/-3.01$ \\
WEIGHT $(\mathrm{kg})$ & $49.51+/-6.08$ \\
HIGH $(\mathrm{cm})$ & $163.90+/-3.00$ \\
XENC $(\mathrm{cm})$ & $88.70+/-3.41$ \\
UC $(\mathrm{cm})$ & $85.90+/-4.38$ \\
ICC $(\mathrm{cm})$ & $92.20+/-4.69$ \\
XN-PS-L $(\mathrm{cm})$ & $34.80+/-1.10$ \\
\hline XENC: abdominal circumference at xiphoid notch level \\
UC: abdominal circumference at umbilical level \\
ICC: abdominal circumference at iliac crest level \\
XN-PS-L: xiphoid notch- pubis symphysis length
\end{tabular}

A midline incision was performed from xiphoid appendix to the pubic symphysis intersected by a transverse incision across the umbilicus. Except for these incisions of the parietal peritoneum, no other peritoneal serous membrane were sectioned during the procedure. This methodology may preserve the morphology and the limits of the peritoneal organs and regions. The lesser sac was reach by blunt dissection separating the coalescence of the greater omentum from the transverse colon according to Lardennois and Okinczyc technique (Lardennois \& Okinczyc, 1913).

All measurements were performed by at least two of the authors. The procedure was a laborious technique: small cellophane films were placed directly onto the peritoneal surfaces successively one next to the other being in contact by the edges. All organs, omenta, mesos, peritoneal ligaments and abdominal walls were covered. The cellophane portions were successively removed and duplicates were done in opaque paper. Digital imaging of the paper patterns was obtained by scanning referring to length. The surface was determined by the "Scion Image Program for Windows".

The reproducibility of the method was checked by measuring 18 times the same section of peritoneum with a mean $+/$ - SE of $25.75+/-0.11 \mathrm{~cm}^{2}$ and a coefficient of variation of $1.83 \%$.
The peritoneal space was considered according to Poirier \& Charpy (1905), Testut \& Latarjet (1975) and Williams.

Eight sub-spaces were considered: right subphrenic, left subphenic, right subhepatic (hepatorenal pouch), left subhepatic, lesser sac (omental bursa), pre greater omentum, retro greater omentum and pelvic sub-space.

For each sub-space was measured the total surface of the peritoneum that limits it with discrimination of their visceral (that cover hollow and solid viscera and laminar structures -omentum, mesos and ligaments-) and parietal (that cover muscles of the anterolateral abdominal walls, the diaphragm, retroperitoneal structures and pelvic walls) portions.

The results were express as mean $+/$ - SE. For the statistical study we used analysis of variance (ANOVA).

\section{RESULTS}

The results are described in Table II and Figures 1 and 2 .

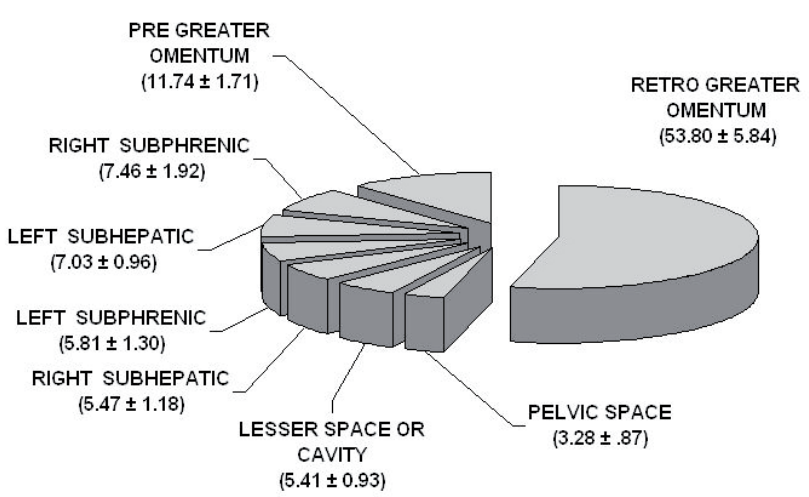

Fig. 1. Areas of peritoneal space $100 \%=$ total peritoneal space surface percentual values expressed as mean \pm SE. $n=10$ cases

Table II shows the extension or surface of total peritoneal (visceral and parietal) that limits each sub-space of the peritoneal space. The visceral sheet measure 11337.99 $\mathrm{cm}^{2}$, the parietal sheet $2985.63 \mathrm{~cm}^{2}$ and the total (both sheets) $14323.62 \mathrm{~cm}^{2}$. We observe the great difference between both peritoneal sheets. This is due to the visceral surface extension and logically visceral peritoneum accompanies the visceral surface.

The retro greater omentum is the sub-space that has the largest total area ( $\mathrm{p}<0.01$ ANOVA). As shown in Figure 
Table II. Measurement of peritoneal extention of all total peritoneal surface (visceral + parietal) that limits to each sub-space of the peritoneal space.

\begin{tabular}{lllllll}
\hline Surface $\left(\mathrm{cm}^{2}\right)$ & Visceral & & Parietal & \multicolumn{3}{l}{ Total } \\
\hline Sub-Space & Media & \pm ES & Media & \pm ES & Media & \pm ES \\
Post Greater Omentum & 7401.82 & 640.9 & 365.99 & 36.8 & 7767.81 & 646,70 \\
Pre Greater Omentum & 984.71 & 82.61 & 652.34 & 52.94 & 1637.05 & 110,24 \\
Right Subphrenic & 538.93 & 42.94 & 539.4 & 36.33 & 1078.33 & 68,85 \\
Left Subhepatic & 727.65 & 43.05 & 281.36 & 21.38 & 1009.01 & 51,20 \\
Left Subphrenic & 346.83 & 29.39 & 481.76 & 40.54 & 828.59 & 48,22 \\
Right Subhepatic & 306.53 & 24.5 & 484.16 & 22.16 & 790.69 & 37,92 \\
Lesser Space Or Cavity & 704.51 & 37.47 & 76.35 & 15.41 & 780.86 & 48,90 \\
& 327.02 & 38.32 & 104.28 & 12.57 & 431.3 & 41,62 \\
Total & 11337.99 & 781.14 & 2985.63 & 115.8 & 14323.62 & 825,41 \\
\hline
\end{tabular}
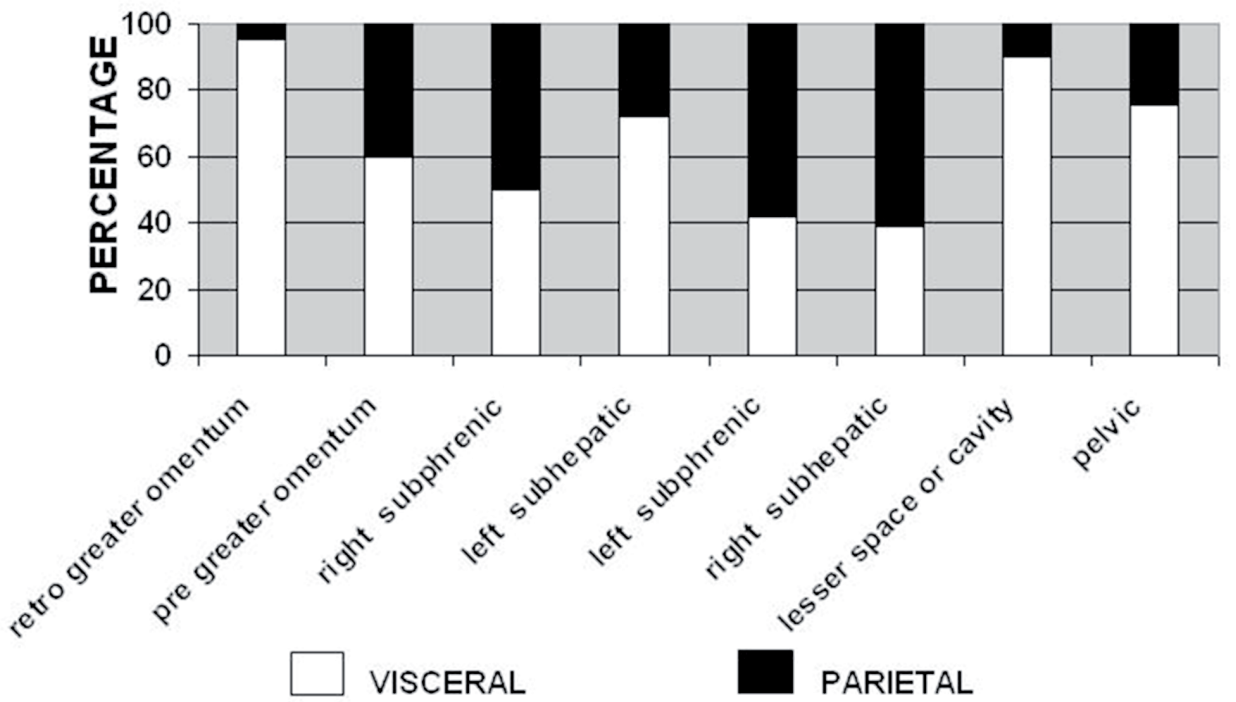

Fig. 2. Percentage of visceral and pariental peritoneal surface correspondig to wall that limits each space. $100 \%=$ Total peritoneal surface that limits each space $\mathrm{n}=10$ cases.
1 more than $50 \%$ of the total peritoneal surface corresponds to this subspace.

Figure 2 shows the visceral and parietal surface percentages that limit each peritoneal subspace. Left subphrenic and right subphrenic differ from the rest of the subspaces and have a greater proportion of surface of its parietal sheet with respect to the visceral sheet.

\section{DISCUSSION}

The present study shows values of surface extensions of total peritoneum, discriminated in visceral and parietal, that limits the different sub-spaces of the peritoneal space. We have not found this type of research in the literature.

From Figure 1, it can be seen that around the $69 \%$ of the peritoneal surface corresponds to inframesocolonic subspace (pre greater omentum, retro greater omentum and pelvic). The supramesocolonic area includes the remaining peritoneal spaces.

From the values in Table II and Figure 1, it can be seen that in the inframesocolonic area (pre greater omentum, retro greater omentum and pelvic sub-spaces) about $77 \%$ of the visceral peritoneum is located, while about $62 \%$ of the parietal peritoneum is located in the supramesocolonic región.

According to Figure 2 the retro greater omentum and lesser space are the sub-spaces with greater relative proportion of visceral peritoneal sheet.

The wide surface of subphrenic sub-spaces limited by a peritoneum with microscopic structure suitable for lymphatic drainage explains the importance of such sub-spaces in the lymphatic drainage of this serosa.

The great development of the blood capillaries in the visceral serosa that forms the laminar structures -mesentery, 
mesos, ligaments- (Schaefer et al., 2016) together with its large peritoneal surface make the retro greater omentum a sub-space of wide peritoneal absorption.

The knowledge of the parietal and visceral sheets discrimination of the total extension of the peritoneum, with the microscopic and functional differences (Witkowicz, 2008; van Baal et al., 2017) adds basic information of clinical interest.

The peritoneal mesothelium, due to great plasticity (Mutsaers, 2002), may be unfavorable in prolonged peritoneal dialysis (Hekking \& van den Born, 2007) with progressive loss of ultrafiltration capability due to structure land functional alterations in the membrane (Twardowski, 2006). In these cases, the estimation of the area involved in each sub-space and the structural differences in each of its sheets can be useful information to evaluate possible treatments (Healy \& Reznek, 1998), On the other hand, this plasticity may be useful in cell transplantation techniques (Kitamura et al., 2014).

The application of local anesthetics in the peritoneal space in surgical procedures (Ioannidis et al., 2013) requires a better knowledge of these peritoneal sub-spaces.

In peritonitis originating in the abdominal viscera, for example, the appendix, the more precise knowledge of the peritoneal sub-spaces involved in the infections process, can help to guide the appropriate surgical and medical treatments (Albanese, 1977).

In pathological processes, such peritoneal carcinomatosis, the information about the sheets of the involved sub-spaces will assist in the estimation of the peritoneal surface affected by the pathology, and it will be possible to evaluate the treatment, such as resections of the affected peritoneum (Deraco et al., 2009; Baratti et al., 2015; Mangeolle et al., 2018; Sugarbaker, 2018) and chemotherapy (Bijelic et al., 2007; Lemoine et al., 2016; Kerbage et al., 2018; Lagast et al., 2018).

The values of the surface areas corresponding to each peritoneal sheets in the different sub-spaces can be the basis for future works that look for a better use of this peritoneal space in the advances of the medicine.

\section{CONCLUSION}

The results obtained shown that the retro greater omentum is the sub-space with the greatest total area of the peritoneal space due to the extension of its visceral surface area. More than $50 \%$ of total peritoneal surface correspond to this sub-space. The smaller space (3\% of the total peritoneal surface) is the pelvic sub-space.

We believe that this information can be useful in cases of pathological peritoneal processes or affected by prolonged peritoneal dialysis. Also the information on the surface of the sub-spaces involved may contribute to the estimation of the peritoneal surface affected and to plan the treatment.

ACKNOWLEDGMENTS. The authors thank Dr. Ricardo J. Losardo, Honorary President of the Pan American Association of Anatomy, for his collaboration in correcting this paper.

ALBANESE, A. M.; MERLO, A. B.; GOMEZ, M. G.; MIÑO, J. H.; INGRATTA, A. V. \& ALBANESE, E. F. Espacios peritoneales. Mediciones de las superficies peritoneales. Int. J. Morphol., 37(2):730-734, 2019.

RESUMEN: En este trabajo se muestran los datos cuantitativos de las superficies que limitan el espacio peritoneal y los sub-espacios que lo componen. La metodología de medición de las dos hojas (parietal y visceral) de la serosa peritoneal empleada en cadáveres no eviscerados, permitió conocer por primera vez, la superficie o extensión total del peritoneo in situ. El objetivo en este trabajo fue determinar -en cadáveres humanos no evisceradoslas áreas peritoneales totales (visceral + parietal) que limitan los distintos sub-espacios que conforman el espacio peritoneal. Se han utilizado diez cadáveres femeninos no eviscerados fijados en solución de formaldehido al $5 \%$. Pequeñas películas de celofán se colocaron directamente sobre las hojas peritoneales. La obtención de imágenes digitales se realizó escaneando estos modelos. La superficie fue determinada por el programa "Scion image for Windows". Los resultados se expresaron como media +/- SE. Para el estudio estadístico se utilizó el análisis de varianza (ANOVA). Los resultados obtenidos demostraron que el sub-espacio peritoneal de mayor superficie fue el retro-omental (media +/- SE 7767,81 +/ - 646,70 $\mathrm{cm}^{2} \mathrm{p}<0.01$ ANOVA), debido a la gran extensión de su superficie visceral (media +/- SE 7401,82 +/- 640,99 cm²). Más del $50 \%$ de la superficie de todo el peritoneo corresponde a dicho sub-espacio. El sub-espacio peritoneal más pequeño (3\% de la superficie peritoneal total) fue el sub-espacio pélvico (media +/$\mathrm{SE} 431,30+/-41,62 \mathrm{~cm}^{2}$ ). Esta información podrá ser de utilidad en el caso de procesos patológicos peritoneales o áreas afectadas por diálisis peritoneal prolongada. De esta manera el conocimiento de la extensión del espacio peritoneal involucrado, puede contribuir a la estimación de la magnitud y gravedad de la superficie peritoneal comprometida. Además puede ayudar a planificar el tratamiento.

PALABRAS ClAVE: Espacio peritoneal; Peritoneo; Morfometría; Anatomía humana. 


\section{REFERENCES}

Albanese, A. M.; Albanese, E. F.; Miño, J. H.; Gómez, E.; Gómez, M.; Zandomeni, M. \& Merlo, A. B. Peritoneal surface area: measurements of 40 structures covered by peritoneum: correlation between total peritoneal surface area and the surface calculated by formulas. Surg. Radiol. Anat., 31(5):369-77, 2009.

Albanese, A. R. El Apéndice, la Apendicitis y la Apendicectomía. Buenos Aires, López, 1977.

Baratti, D.; Kusamura, S.; Guaglio, M. \& Deraco, M. Peritoneal metastases: challenges for the surgeon. Minerva Chir., 70(3):195-215, 2015.

Bijelic, L.; Jonson, A. \& Sugarbaker, P. H. Systematic review of cytoreductive surgery and heated intraoperative intraperitoneal chemotherapy for treatment of peritoneal carcinomatosis in primary and recurrent ovarian cancer. Ann. Oncol., 18(12):1943-50, 2007.

Deraco, M.; Baratti, D.; Kusamura, S.; Laterza, B. \& Balestra, M. R. Surgical technique of parietal and visceral peritonectomy for peritoneal surface malignancies. J. Surg. Oncol., 100(4):321-8, 2009.

Esperanca, M. J. \& Collins, D. L. Peritoneal dialysis efficiency in relation to body weight. J. Pedriatr. Surg., 1(2):162-9, 1966.

Healy, J. C. \& Reznek, R. H. The peritoneum, mesenteries and omenta: normal anatomy and pathological processes. Eur. Radiol., 8(6):886900, 1998.

Hekking, L. H. \& van den Born, J. Feasibility of mesothelial transplantation during experimental peritoneal dialysis and peritonitis. Int. J. Artif. Organs, 30(6):513-9, 2007

Ioannidis, D.; Anastasilakis, C. D.; Vernalidis, I.; Paraskevas , G.; Malakozis, S. G.; Gatzos, S.; Ntoumpara, M.; Tsigkriki, L.; Papapostolou, D.; Makrantonakis, A.; et al. Intraperitoneal administration of local anesthetics in laparoscopic surgery: pharmacological, anatomical, physiological and pathophysiological considerations. Minerva Chir., 68(6):599-612, 2013.

Kerbage, Y.; Canlorbe, G.; Estevez, J. P.; Grabarz, A.; Mordon, S.; Uzan, C.; Collinet, P. \& Azaï, H. Microscopic peritoneal metastases of epithelial ovarian cancers. Clinical relevance, diagnostic and therapeutic tools. Gynecol. Obstet. Fertil. Senol., 46(5):497-502, 2018.

Kitamura, S; Horimoto, N.; Tsuji, K.; Inoue, A.; Takiue, K.; Sugiyama, H. \& Makino, H. The selection of peritoneal mesothelial cells is important for cell therapy to prevent peritoneal fibrosis. Tissue Eng. Part A, 20(3-4):529-39, 2014.

Lagast, N.; Carlier, C. \& Ceelen, W. P. Pharmacokinetics and tissue transport of intraperitoneal chemotherapy. Surg. Oncol. Clin. N. Am., 27(3):477-94, 2018.

Lardennois, G. \& Okinczyc, J. Typhiosigmoidostomie in Y dans le traitment des coutesrebelles et de la ultimae du grosintestin. Bull. Mem. Soc. Anat. Paris, 39:858-72, 1913

Lemoine, L.; Sugarbaker, P. \& Van der Speeten, K. Pathophysiology of colorectal peritoneal carcinomatosis: Role of the peritoneum. World J. Gastroenterol., 22(34):7692-707, 2016.

Mangeolle, T.; Yakavets, I.; Marchal, S.; Debayle, M.; Pons, T.; Bezdetnaya, L. \& Marchal, F. Fluorescent nanoparticles for the guided surgery of ovarian peritoneal carcinomatosis. Nanomaterials (Basel), 8(8):E572, 2018.

Mutsaers, S. E. Mesothelial cells: their structure, function and role in serosal repair. Respirology, 7(3):171-91, 2002.

Poirier, P. \& Charpy, A. Traité d'Anatomie Humaine. $12^{\text {st }}$ ed. Paris, Masson, 1905.

Rubin, J.; Clawson, M.; Planch, A. \& Jones, Q. Measurements of peritoneal surface area in man and rat. Am. J. Med. Sci., 295(5):453-8, 1988.

Schaefer, B.; Bartosova, M.; Macher-Goeppinger, S.; Ujszaszi, A.; Wallwiener, M.; Nyarangi-Dix, J.; Sallay, P.; Burkhardt, D.; Querfeld, U.; Pfeifle, V.; et al. Quantitative histomorphometry of the healthy peritoneum. Sci. Rep., 6:21344, 2016.
Sugarbaker, P. H. Peritoneal metastases, a frontier for progress. Surg. Oncol. Clin. N. Am., 27(3):413-24, 2018.

Testut, L. \& Latarjet, A. Tratado de Anatomía Humana. $9^{\text {th }}$ ed. Barcelona, Salvat, 1975.

Twardowski, Z. J. Pathophysiology of peritoneal transport. Contrib. Nephrol., 150:13-9, 2006.

van Baal, J. O.; Van de Vijver, K. K.; Nieuwland, R.; van Noorden, C. J.; van Driel, W. J.; Sturk, A.; Kenter, G. G.; Rikkert, L. G. \& Lok, C. A. The histophysiology and pathophysiology of the peritoneum. Tissue Cell, 49(1):95-105, 2017.

Williams, P. L. Gray'S Anatomy. The Anatomical Basis of Medicine and Surgery. $38^{\text {st }}$ ed. New York, Churchill Livingstone, 1995.

Witkowicz, J. Mesothelial cell transplantation. Pol. Arch. Med. Wewn., 118(5):307-13, 2008

Corresponding author:

Alfonso M. Albanese

Cátedra de Anatomía

Instituto de Investigaciones

Facultad de Medicina

Universidad del Salvador

Buenos Aires

ARGENTINA

\section{Email: efalbanese@hotmail.com}

Received: 22-11-2018

Accepted: 04-02-2019 